\title{
Faktor-Faktor yang Berhubungan dengan Stunting Sangat Pendek dan Pendek pada Anak Usia 24-59 Bulan di Kecamatan Sawah Besar
}

\author{
Luluk Atmi Rahmawati, Fathinah Ranggauni Hardy, Ayu Anggraeni Dyah Purbasari \\ Program Studi S1 Kesehatan Masyarakat, Fakultas Ilmu Kesehatan \\ Universitas Pembangunan Nasional Veteran Jakarta
}

\begin{abstract}
Abstrak
Latar Belakang: Salah satu masalah gizi yang dihadapi oleh Indonesia adalah kejadian balita pendek (stunting). Stunting adalah hal yang sangat penting karena akan memengaruhi sumber daya manusia di masa depan.

Metode: Desain penelitian ini menggunakan studi cross sectional dengan total sampel 91 balita stunting berusia 24-59 bulan. Teknik pengambilan sampel yang digunakan adalah purposive sampling.

Hasil: Balita pendek lebih banyak (76,9\%) daripada balita sangat pendek (23,1\%). Tidak ada hubungan antara usia Ibu ( $p$ value=0,503), pendidikan Ibu ( $p$ value $=0,924)$, status pekerjaan ( $p$ value $=0,737)$, pendapatan keluarga ( $p$ value $=0,534)$, pengetahuan Ibu ( $p$ value $=0,829)$, ragam makanan ( $p$ value $=0,893$ ), riwayat penyakit ( $p$ value $=0,348)$, pola istirahat ( $p$ value $=0,714)$, dan aktivitas fisik $(p$ value $=0,171)$ dengan stunting sangat pendek dan pendek. Ada hubungan antara ASI eksklusif ( $p$ value $=0,006)$, dan pola asuh ( $p$ value $=0,004$ ) dengan stunting sangat pendek dan pendek. Kesimpulan: Ada hubungan antara ASI eksklusif dan pola asuh dengan stunting sangat pendek dan pendek. Dalam hal ini maka perlu diadakannya sosialisasi pada orang tua balita mengenai pemberian ASI eksklusif dan praktik pola asuh yang baik dan benar
\end{abstract}

Kata kunci: stunting, sangat pendek, balita, pola asuh

\section{Related Factors of Very Short and Short Stunting In Children Aged 24-59 Months in Kecamatan Sawah Besar}

\begin{abstract}
Background: One of the nutritional problems faced by Indonesia is the occurrence of short toddlers (stunting). Stunting is very important because it will affect human resources in the future.

Methods: The design of this study used a cross sectional study with a total sample of 91 stunting toddlers aged 24-59 months. The sampling technique used was purposive sampling

Results: Stunting are more (76.9\%) than severe stunting (23.1\%). There were no correlation between mother's age ( $p$ value $=0.503)$, mother education ( $p$ value $=0.924)$, employment status ( $p$ value $=$ $0.737)$, family income ( $p$ value $=0.534)$, mother's knowledge ( $p$ value $=0.829)$, variance foods $(p$ value $=0.893)$, disease history $(p$ value $=0.348)$, rest pattern $(p$ value $=0.714)$, and physical activity ( $p$ value $=0.171)$ with stunting and severe stunting. There were have correlation between exclusive breastfeeding $(p$ value $=0.006)$, and parenting $(p$ value $=0.004)$ with severe stunting and stunting.

Conclusions: There were have correlation between exclusive breastfeeding and parenting with a severe stunting and stunting. In this case, it is necessary to have more socialization for parents about exclusive breastfeeding practice and parenting practices in the right way.
\end{abstract}

Keywords: stunting, severely stunting, toodler, parenting

Alamat Korespondensi :

Fathinah Ranggauni Hardy

Fakultas Ilmu Kesehatan, Universitas Pembangunan

Nasional Veteran Jakarta, Jl. Raya Limo, Depok

Email: Fathinahranggaunihardy@gmail.com 


\section{PENDAHULUAN}

Salah satu masalah gizi yang dihadapi oleh Indonesia adalah kejadian balita pendek (stunting). Stunting adalah hal yang sangat penting karena akan memengaruhi sumber daya manusia di masa depan. Balita stunting mudah terjangkit penyakit dan bisa menderita penyakit degeneratif saat dewasa. Dalam mencegah dan menurunkan angka kejadian stunting tidak hanya dilakukan oleh sektor kesehatan saja tetapi harus mengikutsertakan lintas sektor ${ }^{1}$.

Stunting dibedakan menjadi dua kategori severely stunted (sangat pendek) dan stunted (pendek). Anak dapat dikatakan sangat pendek (severely stunted) jika tinggi atau panjang badan kurang dari 3 kali standar deviasi $(<-3$ SD) sedangkan anak dikatakan pendek (stunted) apabila tinggi atau panjang badannya $-3 \mathrm{SD}$ sampai dengan $-2 \mathrm{SD}^{2}$.

Prevalensi stunting meningkat dari 27,5\% (2016) menjadi 29,6\% (2017) ${ }^{3}$. Menurut survei PSG yang yang dilaksanakan dalam rangka untuk monitoring, evaluasi kerja dan capaian suatu program menunjukkan bahwa prevalensi balita sangat pendek meningkat dari 8,5\% menjadi 9,8\% (2017) dan balita pendek $19 \%$ menjadi $19,8 \%$ (2017) ${ }^{2}$. Sama halnya dengan data Riskesdas (2018) yang menunjukkan bahwa prevalensi balita pendek mengalami peningkatan dari 19,2\% tahun 2013 menjadi 19,3\% pada tahun 2018 sedangkan balita sangat pendek mengalami penurunan dari 18\% pada tahun 2013 menjadi 11,5\% pada tahun 2018.

Selain dapat merugikan bagi kesehatan dan tumbuh kembang anak, stunting (sangat pendek dan pendek) juga akan mengakibatkan perkembangan kognitiif, motorik dan mental sosial anak terganggu dan kedepannya akan memengaruhi produktivitasnya dalam bekerja saat dewasa nanti. Anak yang stunting juga meiliki riiko lebih besar untuk menderita penyakit degeneratif saat masa tuanya Dalam segi ekonomi, pembiayaan kesehatan yang meningkat juga merupakan salah satu dampak dari stunting, menurut laporan World Bank tahun 2016 bahwa negara memiliki potensi kerugian ekonomi yang dikaibatkan stunting sebesar 2-3\% Produk Domestik Bruto (PDB). Oleh karena itu, potensi kerugian ekonomi yang mungkin dialami Indonesia sebesar Rp. 260-390 trilyun per tahun jika PDB sebesar Rp. 13.000 triliyun ${ }^{3}$. Faktor yang memengaruhi stunting pada balita berdasarkan penelitian diantaranya usia Ibu, pendidikan ibu, status pekerjaan ibu, pendapatan keluarga, pengetahuan ibu dan pola asuh gizi yang meliputi ASI eksklusif dan MP-ASI serta riwayat penyakit anak.

Pada umumnya penyakit infeksi disebabkan oleh praktik kebersihan dan sanitasi yang buruk, penyakit infeksi yang sering diderita anak seperti, kecacingan dan diare dapat memengaruhi nafsu makan anak dan mengganggu penyerapan nutrisi dalam proses percenaan. Jika penyakit infeksi yang diderita tidak kunjung sembuh dalam waktu yang lama, maka secara tidak langsung hal ini akan mengakibatkan berat badan anak menurun yang dikarenakan asupan gizi kurang sehingga berakibat menderita stunting. Selain itu, penyebab tidak langsung terjadinya stunting adalah pola asuh yang kurang baik. Menurut UNICEF/Lancet, masalah stunting disebabkan oleh adanya pengaruh pola asuh tidak baik (IMD, ASI eksklusif, pemberian ASI dan dilanjutkan dengan MPASI sampai anak berusia 2 tahun), kualitas kesehatan yang kurang baik dan cakupan pelayanan kesehatan yang kurang ${ }^{3}$.

Berdasarkan hasil penelitian Ni'mah C dan Muniroh L (2015) menunjukkan bahwa masalah stunting lebih banyak terjadi pada balita miskin dibandingkan masalah wasting. Kejadian tersebut tidak memiliki hubungan dengan tingkat pendidikan Ibu, tingkat pengetahuan ibu dan pola asuh (Ni 'mah dan Muniroh, 2015). Hasil penelitian Aisyah dkk. (2019) juga menunjukkan bahwa tidak ada hubungan signifikan antara pola asuh gizi dengan stunting pada anak baru masuk sekolah dasar di Daerah Pesisir Kota Semarang ${ }^{5}$. Beda halnya dengan hasil penelitian Farah Danita Rahman (2018) menyatakan bahwa pola pemberian makan yang buruk akan meningkatkan risiko perbedaan sangat pendek dan pendek pada balita ${ }^{6}$.

Data PSG tahun 2017 memperlihatkan bahwa prevalensi balita stunting lebih tinggi yaitu 29,6\% dibandingkan pada baduta sebesar 20,1\%. Berdasarkan Profil Kesehatan Indonesia (2017), prevalensi balita pendek umur 0-59 bulan di DKI Jakarta sebesar $13,78 \%$ ? . Sedangkan, menurut data PSG prevalensi stunting balita di DKI Jakarta merupakan prevalensi terbesar dibandingkan 
dengan masalah gizi pada balita lainnya (Underweight, Wasting, Gemuk) yaitu sebesar 22,7\% yang termasuk kedalam karakteristik akut-kronis. Prevalensi stunting terbesar di DKI Jakarta adalah di DKI Jakarta yaitu sebesar 29,2\% dengan karakteristik masalah gizi akut-kronis ${ }^{2}$. Kejadian stunting bukan hanya menjadi masalah kesehatan dan gizi saja tetapi juga menyangkut sarana dan prasarana untuk masyarakat $^{8}$.

Hasil rekapan status gizi balita yang telah terkonfirmasi berdasarkan EPBGM wilayah kota administrasi DKI Jakarta tahun 2018 didapat data bahwa prevalensi stunting pada balita terbesar berada pada kecamatan Sawah Besar yaitu sebesar 5,3\% dengan jumlah kasus 201 orang (kasus dengan 129 balita pendek dan 72 balita sangat pendek ${ }^{9}$.

Berdasarkan latar belakang masalah diatas, maka masalah tersebut penting untuk diteliti dengan judul penelitian "Faktor-faktor yang Berhubungan dengan Perbedaan Sangat Pendek dan Pendek Pada Anak Usia 24-59 bulan di Puskesmas Sawah Besar, DKI Jakarta"

\section{METODE}

Desain penelitian ini menggunakan studi cross sectional. Penelitian ini dilaksanakan di wilayah Kerja Puskesmas Kecamatan Sawah Besar, DKI Jakarta. Pengumpulan data pada penelitian ini dilakukan pada bulan Mei - Juni 2019. Teknik pengambilan sampel penelitian ini yaitu purposive sampling berdasarkan kriteria inklusi dan kriteria eksklusi. Sampel dalam penelitian ini adalah seluruh anak usia 24-59 bulan di
Wilayah Kerja Puskesmas Kecamatan Sawah Besar, DKI Jakarta yang berjumlah 83 orang. Variabel independen dalam penelitian ini adalah karakteristik Ibu, pola asuh gizi, riwayat penyakit, pola istirahat dan aktivitas fisik. Variabel dependen dalam penelitian ini stunting sangat pendek dan pendek di Kecamatan Sawah Besar, DKI Jakarta. Data primer yaitu data yang langsung diperoleh dari responden berupa data tinggi badan anak, umur anak, jenis kelamin anak, nama orang tua (ibu), pendidikan ibu, status pekerjaan ibu, pendapatan keluarga per bulan, pola asuh gizi, riwayat penyakit anak, aktivitas fisik anak, pola istirahat dan pengetahuan ibu dan asupan makanan pada anak usia 24-59 bulan. Data berat badan dan tinggi badan diperoleh melalui pengukuran tinggi badan anak dengan menggunakan microtoise dan penimbangan dilakukan dengan timbangan berat badan. Data sekunder yaitu data yang diperoleh dari Sudinkes Jakarta Pusat dan Puskesmas Sawah Besar. Data yang diperoleh berupa data jumlah anak balita usia 24-59 bulan yang menderita stunting.

\section{HASIL}

Hubungan Usia Ibu dengan Stunting Sangat Pendek dan Pendek

Hasil analisis uji statistik menunjukkan bahwa tidak ada hubungan yang signifikan antara usia Ibu dengan stunting sangat pendek dan pendek pada balita stunting di Kecamatan Sawah Besar Kota Jakarta Pusat dengan hasil $\mathrm{p}$ value $>0.05$ yaitu $\mathrm{p}$ value $=0.503$.

Tabel 1 Analisis Hubungan antara Usia Ibu, Pendidikan Ibu, Status Pekerjaan Ibu, Pendapatan Keluarga, Pengetahuan Ibu, ASI Eksklusif, Ragam Makanan, Pola asuh, Riwayat Penyakit, Pola Istirahat dan Aktivitas Fisik

\begin{tabular}{|c|c|c|c|c|c|c|c|c|c|c|}
\hline \multirow{3}{*}{ No. } & \multirow{3}{*}{ Variabel } & \multirow{3}{*}{ Kategori } & \multicolumn{4}{|c|}{ Stunting } & \multirow{2}{*}{\multicolumn{2}{|c|}{ Jumlah }} & \multirow{3}{*}{ P Value } & \multirow{3}{*}{ CI 95\% } \\
\hline & & & \multicolumn{2}{|c|}{$\begin{array}{l}\text { Sangat } \\
\text { Pendek }\end{array}$} & \multicolumn{2}{|c|}{ Pendek } & & & & \\
\hline & & & $\mathrm{n}$ & $\%$ & $\mathbf{n}$ & $\%$ & $\mathbf{n}$ & $\%$ & & \\
\hline \multirow{2}{*}{1.} & \multirow{2}{*}{ Usia Ibu } & $<29$ tahun & 12 & 27.3 & 32 & 72.7 & 44 & 100 & \multirow{2}{*}{0.503} & \multirow{2}{*}{$0.236-1.689$} \\
\hline & & $\geq 29$ tahun & 9 & 19.1 & 38 & 80.9 & 47 & 100 & & \\
\hline \multirow{2}{*}{2.} & \multirow{2}{*}{$\begin{array}{l}\text { Pendidikan } \\
\text { Ibu }\end{array}$} & Rendah & 12 & 24.5 & 37 & 75.5 & 49 & 100 & \multirow{2}{*}{0.924} & \multirow{2}{*}{$0.315-2.248$} \\
\hline & & Tinggi & 9 & 21.5 & 33 & 78.6 & 42 & 100 & & \\
\hline \multirow[t]{2}{*}{3.} & \multirow{2}{*}{$\begin{array}{l}\text { Status } \\
\text { Pekerjaan } \\
\text { Ibu }\end{array}$} & $\begin{array}{l}\text { Tidak } \\
\text { Bekerja }\end{array}$ & 17 & 24.6 & 52 & 75.4 & 69 & 100 & \multirow[t]{2}{*}{0.737} & \multirow[t]{2}{*}{$0.437-4.953$} \\
\hline & & Bekerja & 4 & 18.2 & 18 & 81.8 & 91 & 100 & & \\
\hline \multirow{2}{*}{4.} & Pendapatan & $<\mathrm{UMP}$ & 17 & 22.7 & 58 & 77.3 & 75 & 100 & \multirow{2}{*}{0.534} & \multirow{2}{*}{$0.325-3.986$} \\
\hline & Keluarga & $\geq$ UMP & 4 & 25 & 12 & 75 & 16 & 100 & & \\
\hline
\end{tabular}




\begin{tabular}{|c|c|c|c|c|c|c|c|c|c|c|}
\hline \multirow{3}{*}{ No. } & \multirow{3}{*}{ Variabel } & \multirow{3}{*}{ Kategori } & \multicolumn{4}{|c|}{ Stunting } & \multirow{2}{*}{\multicolumn{2}{|c|}{ Jumlah }} & \multirow{3}{*}{ P Value } & \multirow{3}{*}{ CI $95 \%$} \\
\hline & & & \multicolumn{2}{|c|}{$\begin{array}{l}\text { Sangat } \\
\text { Pendek }\end{array}$} & \multicolumn{2}{|c|}{ Pendek } & & & & \\
\hline & & & $\mathbf{n}$ & $\%$ & $\mathbf{n}$ & $\%$ & $\mathbf{n}$ & $\%$ & & \\
\hline \multirow{2}{*}{5.} & \multirow{2}{*}{$\begin{array}{l}\text { Pengetahua } \\
\text { n Ibu }\end{array}$} & Kurang & 9 & 25.7 & 26 & 74.3 & 35 & 100 & \multirow{2}{*}{0.829} & \multirow{2}{*}{$0.471-3.419$} \\
\hline & & Baik & 12 & 21.4 & 44 & 78.6 & 56 & 100 & & \\
\hline \multirow{2}{*}{6.} & \multirow{2}{*}{$\begin{array}{l}\text { ASI } \\
\text { Eksklusif }\end{array}$} & Tidak & 20 & 32.3 & 42 & 67.7 & 62 & 100 & \multirow{2}{*}{0.006} & \multirow{2}{*}{$0.010-0.591$} \\
\hline & & $\mathrm{Ya}$ & 1 & 3.4 & 28 & 96.6 & 29 & 100 & & \\
\hline \multirow[t]{2}{*}{7.} & \multirow{2}{*}{$\begin{array}{l}\text { Ragam } \\
\text { Makanan }\end{array}$} & $\begin{array}{l}\text { Tidak } \\
\text { Beragam }\end{array}$ & 10 & 25 & 30 & 75 & 40 & 100 & \multirow{2}{*}{0.893} & \multirow{2}{*}{$0.456-3.225$} \\
\hline & & Beragam & 11 & 21.6 & 40 & 78.4 & 51 & 100 & & \\
\hline \multirow{2}{*}{8.} & \multirow{2}{*}{ Pola Asuh } & Kurang & 15 & 39.5 & 23 & 60.5 & 38 & 100 & \multirow{2}{*}{0.004} & \multirow{2}{*}{$1.752-14.895$} \\
\hline & & Baik & 6 & 11.3 & 47 & 88.7 & 53 & 100 & & \\
\hline \multirow{2}{*}{9.} & \multirow{2}{*}{$\begin{array}{l}\text { Riwayat } \\
\text { Penyakit }\end{array}$} & $\begin{array}{l}\text { Tidak Ada } \\
\text { Riwayat }\end{array}$ & 8 & 17.8 & 37 & 82.2 & 45 & 100 & \multirow{2}{*}{0.348} & \multirow{2}{*}{$0.672-4.942$} \\
\hline & & $\begin{array}{l}\text { Ada } \\
\text { Riwayat }\end{array}$ & 13 & 28.3 & 33 & 71.7 & 45 & 100 & & \\
\hline \multirow{2}{*}{10.} & \multirow{2}{*}{$\begin{array}{l}\text { Pola } \\
\text { Istirahat }\end{array}$} & Kurang & 13 & 25.5 & 38 & 74.5 & 51 & 100 & \multirow{2}{*}{0.714} & \multirow{2}{*}{$0.504-3.714$} \\
\hline & & Baik & 8 & 20.0 & 32 & 80.0 & 40 & 100 & & \\
\hline \multirow{2}{*}{11.} & \multirow{2}{*}{$\begin{array}{l}\text { Aktivitas } \\
\text { Fisik }\end{array}$} & Ringan & 13 & 29.4 & 36 & 70.6 & 51 & 100 & 0171 & \\
\hline & & Berat & 8 & 15.0 & 34 & 85.0 & 40 & 100 & $0.1 / 1$ & $0.821-0.191$ \\
\hline
\end{tabular}

\section{Hubungan Status Pekerjaan Ibu dengan Stunting Sangat Pendek dan Pendek}

Berdasarkan hasil penelitian didapatkan data bahwa Ibu yang tidak bekerja cenderung memiliki balita sangat pendek lebih besar dari Ibu yang bekerja, yaitu sebesar 17 balita dan 4 balita. Sama halnya, Ibu yang tidak bekerja cenderung memiliki anak dengan kategori pendek lebih besar dibandingkan ibu yang bekerja yaitu sebesar 52 balita dan 18 balita.

Hasil analisis uji statistik diperoleh hasil $\mathrm{p}$ value $>0.05$ yaitu $\mathrm{p}$ value $=0.737$ yang berarti tidak terdapat hubungan yang signifikan antara status pekerjaan Ibu dengan stunting sangat pendek dan pendek pada balita stunting di Kecamatan Sawah Besar Kota Jakarta Pusat.

\section{Hubungan Pendapatan Keluarga dengan Stunting Sangat Pendek dan Pendek}

Berdasarkan hasil penelitian didapatkan data bahwa keluarga yang berpendapatan dibawah UMP cenderung memiliki balita sangat pendek lebih besar dari keluarga yang berpendapatan diatas UMP, yaitu sebesar 17 balita dan 4 balita. Sama halnya, Ibu yang berpendidikan rendah cenderung memiliki anak dengan kategori pendek lebih besar dibandingkan ibu yang berpendidikan tinggi yaitu sebesar 58 balita dan 12 balita.

Hasil analisis uji statistik diperoleh hasil $\mathrm{p}$ value $>0.05$ yaitu $\mathrm{p}$ value $=0.534$ yang berarti tidak terdapat hubungan yang signifikan antara pendapatan keluarga dengan stunting sangat pendek dan pendek pada balita stunting di Kecamatan Sawah Besar Kota Jakarta Pusat.

Hubungan Pengetahuan Ibu dengan Stunting Sangat Pendek dan Pendek

Berdasarkan hasil penelitian didapatkan data bahwa Ibu dengan pengetahuan baik cenderung memiliki balita sangat pendek lebih besar dari Ibu dengan pengetahuan kurang, yaitu sebesar 12 balita dan 9 balita.Sama halnya, Ibu dengan pendidikan baik cenderung memiliki anak dengan kategori pendek lebih besar dibandingkan ibu dengan pengetahuan kurang yaitu sebesar 44 balita dan 26 balita.

Hasil analisis uji statistik diperoleh hasil $\mathrm{p}$ value $>0.05$ yaitu $\mathrm{p}$ value $=0.829$ yang berarti tidak terdapat hubungan yang signifikan antara pengetahuan Ibu dengan stunting sangat pendek dan pendek pada balita stunting di Kecamatan Sawah Besar Kota Jakarta Pusat.

\section{Hubungan ASI Eksklusif dengan Stunting Sangat Pendek dan Pendek}

Berdasarkan hasil penelitian didapatkan data bahwa balita yang tidak mendapatkan ASI eksklusif cenderung menderita sangat pendek lebih besar dari balita yang mendapatkan ASI eksklusif, yaitu sebesar 20 balita dan 1 balita. Sama halnya, balita yang tidak mendapatkan ASI eksklusif cenderung menderita pendek 
lebih besar dari balita yang mendapatkan ASI eksklusif yaitu sebesar 42 balita dan 28 balita.

Hasil analisis uji statistik diperoleh hasil $\mathrm{p}$ value $>0.05$ yaitu $\mathrm{p}$ value $=0.006$ yang berarti terdapat hubungan yang signifikan antara ASI eksklusif dengan stunting sangat pendek dan pendek pada balita stunting di Kecamatan Sawah Besar Kota Jakarta Pusat.

\section{Hubungan Ragam Makanan dengan Stunting Sangat Pendek dan Pendek}

Berdasarkan hasil penelitian didapatkan data bahwa balita yang mengonsumsi makanan beragam cenderung menderita sangat pendek lebih besar dari balita pendek yang tidak mengonsumsi makanan beragam, yaitu sebesar 11 balita dan 10 balita. Sama halnya, balita yang balita yang mengonsumsi makanan beragam cenderung menderita pendek lebih besar dari balita yang tidak mengonsumsi makanan beragam, yaitu sebesar 40 balita dan 30 balita.

Hasil analisis uji statistik diperoleh hasil $\mathrm{p}$ value $>0.05$ yaitu $\mathrm{p}$ value $=0.893$ yang berarti tidak terdapat hubungan yang signifikan antara ragam makanan dengan stunting sangat pendek dan pendek pada balita stunting di Kecamatan Sawah Besar Kota Jakarta Pusat.

\section{Hubungan Pola asuh dengan Stunting Sangat Pendek dan Pendek}

Berdasarkan hasil penelitian didapatkan data bahwa balita dengan pola asuh kurang cenderung menderita sangat pendek lebih besar dari balita dengan pola asuh baik, yaitu sebesar 15 balita dan 6 balita. Sebaliknya, balita dengan pola asuh baik cenderung menderita pendek lebih besar dari balita dengan pola asuh kurang, yaitu sebesar 47 balita dan 23 balita

Hasil analisis uji statistik diperoleh hasil $\mathrm{p}$ value $>0.05$ yaitu $\mathrm{p}$ value $=0.004$ yang berarti terdapat hubungan yang signifikan antara pola asuh dengan stunting sangat pendek dan pendek pada balita stunting di Kecamatan Sawah Besar Kota Jakarta Pusat.

\section{Hubungan Riwayat Penyakit dengan Stunting Sangat Pendek dan Pendek}

Berdasarkan hasil penelitian didapatkan data bahwa balita sangat pendek yang memiliki riwayat penyakit lebih besar dibandingkan balita sangat pendek yang tidak memiliki riwayat penyakit, yaitu sebesar 13 balita dan 8 balita. Sebaliknya, balita pendek yang tidak memiliki riwayat penyakit lebih besar dibandingkan balita pendek yang memiliki riwayat penyakit, yaitu sebesar 37 balita dan 33 balita

Hasil analisis uji statistik diperoleh hasil $\mathrm{p}$ value $>0.05$ yaitu $\mathrm{p}$ value $=0.348$ yang berarti tidak terdapat hubungan yang signifikan antara riwayat penyakit dengan stunting sangat pendek dan pendek pada balita stunting di Kecamatan Sawah Besar Kota Jakarta Pusat.

\section{Hubungan Pola Istirahat dengan Stunting Sangat Pendek dan Pendek}

Berdasarkan hasil penelitian didapatkan data bahwa balita sangat pendek dengan pola istirahat kurang lebih besar dibandingkan balita sangat pendek yang dengan pola istirahat baik, yaitu sebesar 13 balita dan 8 balita. Sebaliknya, balita pendek dengan pola istirahat kurang lebih besar dibandingkan balita pendek dengan pola istirahat baik, yaitu sebesar 38 balita dan 32 balita.

Hasil analisis uji statistik diperoleh hasil $\mathrm{p}$ value $>0.05$ yaitu $\mathrm{p}$ value $=0.714$ yang berarti tidak terdapat hubungan yang signifikan antara pola istirahat dengan stunting stunting pada balita stunting di Kecamatan Sawah Besar Kota Jakarta Pusat.

\section{Hubungan Aktivitas Fisik dengan Stunting Sangat Pendek dan Pendek}

Berdasarkan hasil penelitian didapatkan data bahwa balita sangat pendek dengan aktivitas fisik ringan lebih besar dibandingkan balita sangat pendek yang dengan aktivitas fisik berat, yaitu sebesar 13 balita dan 8 balita. Sebaliknya, balita pendek dengan aktivitas fisik ringan lebih besar dibandingkan balita pendek dengan aktivitas fisik berat, yaitu sebesar 36 balita dan 34 balita.

Hasil analisis uji statistik diperoleh hasil $\mathrm{p}$ value $>0.05$ yaitu $\mathrm{p}$ value $=0.714$ yang berarti tidak terdapat hubungan yang signifikan antara pola istirahatdengan perbedaan sangat pendek dan pendek pada balita stunting di Kecamatan Sawah Besar Kota Jakarta Pusat.

\section{PEMBAHASAN}

\section{Hubungan Usia Ibu dengan Stunting Sangat Pendek dan Pendek}

Usia akan berpengaruhi pada kemampuan dan kesiapan seorang ibu. Umur ibu menentukan pola pengasuhan dan penentuan makanan yang sesuai bagi anaknya karena semakin bertambahnya umur ibu maka semakin bertambah pengalaman dan 
kematangan ibu dalam pola pengasuhan dan penentuan makan anak ${ }^{10}$.

Hasil analisis uji statistik menunjukkan bahwa tidak ada hubungan yang signifikan antara usia Ibu dengan stunting sangat pendek dan pendek pada balita stunting di Kecamatan Sawah Besar Kota Jakarta Pusat. Hasil ini sejalan dengan penelitian Hayyudini dkk. (2017) yang menunjukkan bahwa tidak ada hubungan yang signifikan antara usia ibu dengan status gizi anak di wilayah kerja Puskesmas Kedungmundu Kota Semarang tahun 2017. Usia 20-35 tahun adalah usia yang matang untuk berlangsungnya kehamilan. Sebab, Ibu yang berusia 20-35 tahun akan memiliki kesungguhan dalam merawat, mengasuh serta membesarkan anaknya. Akan tetapi, dalam kenyataannya pada usia tersebut masih terdapat Ibu yang belum paham dan belum menerapkan pengasuhan yang baik dalam mengasuh anaknya. Terlebih khusus dalam pemilihan makanan tepat untuk anak ${ }^{11}$.

\section{Hubungan Status Pekerjaan Ibu dengan Stunting Sangat Pendek dan Pendek}

Berdasarkan hasil penelitian

didapatkan data bahwa Ibu yang tidak bekerja cenderung memiliki balita sangat pendek lebih besar dari Ibu yang bekerja. Tidak terdapat hubungan yang signifikan antara status pekerjaan Ibu dengan stunting sangat pendek dan pendek pada balita stunting di Kecamatan Sawah Besar Kota Jakarta Pusat. Hal ini tidak sejalan dengan penelitian Wahdah dkk. (2015) yang menyatakan bahwa pekerjaan ibu mempunyai hubungan yang signifikan dengan perbedaan sangat pendek dan pendek. Anak dari ibu-ibu yang bekerja akan lebih berisiko untuk menderita stunting jika dibandingkan dengan ibu yang tidak bekerja. Hal ini berpengaruh terhadap terhadap kecukupan gizi dalam keluarga, terutama pada anak balita yang memerlukan asupan gizi optimal untuk pertumbuhannya. Sebaliknya, pada ibu yang tidak bekerja atau hanya sebagai ibu rumah tangga memipunyai peluang yang cukup baik dalam mengasuh dan merawat anaknya ${ }^{12}$.

Hasil ini sejalan dengan penelitian Aridiyah dkk. (2015) yang menyatakan bahwa perbedaan sangat pendek dan pendek pada anak balita secara signifikan tidak memiliki hubungan dan penelitian Aisyah dkk. (2019) yang mengemukakan bahwa tidak ada hubungan antara pekerjaan dengan stunting. Menurut hasil penelitian, Ibu yang bekerja cenderung lebih banyak dibandingkan dengan yang Ibu tidak bekerja. Pekerjaan Ibu di Kecamatan Sawah Besar sebagian besar sebagai karyawati yang bekerja di sebuah toko atau pusat perbelanjaan, serta pekerjaan lainnya beragam ada yang berdagang karena pemukiman pendudukan dekat dengan pasar ada juga yang bekerja sebagai kuli cuci.

\section{Hubungan Pendapatan Keluarga dengan Stunting Sangat Pendek dan Pendek}

Berdasarkan hasil penelitian didapatkan data bahwa keluarga yang berpendapatan dibawah UMP cenderung memiliki balita sangat pendek lebih besar dari keluarga yang berpendapatan diatas UMP. Tidak terdapat hubungan yang signifikan antara pendapatan keluarga dengan stunting sangat pendek dan pendek pada balita stunting di Kecamatan Sawah Besar Kota Jakarta Pusat. Hal ini sejalan dengan penelitian Windi (2018) yang menyatakan bahwa pendapatan keluarga tidak memiliki hubungan yang signifikan dengan perbedaan sangat pendek dan pendek. Berbeda halnya dengan penelitian Nkurunziza dkk., (2017) menyatakan bahwa keluarga dengan status sosial ekonomi kurang mampu berhubungan dengan stunting sangat pendek dan pendek. Jika ditinjau dari karakteristik pandapatan keluarga bahwa akar masalah dari dampak pertumbuhan bayi dan berbagai masalah gizi lainnya salah satunya disebabkan dan berasal dari krisis ekonomi. Sebagian besar anak balita yang mengalami gangguan pertumbuhan diantaranya memiliki status ekonomi yang rendah ${ }^{13}$.

Status ekonomi rendah dianggap memiliki pengaruh dominan terhadap kejadian wasting dan stunting pada anak ${ }^{14}$. Orang tua dengan pendapatan keluarga yang memadai akan memiliki kemampuan untuk menyediakan semua kebutuhan primer dan sekunder anak. Keluarga dengan status ekonomi baik juga mempunyai akses pelayanan kesehatan yang lebih baik (Soetjiningsih dalam Setiawan, Machmud dan Masrul, 2018) anak pada keluarga dengan status ekonomi yang rendah cenderung mengonsumsi makanan dalam segi kuantitas, kualitas dan variasi yang kurang. Status ekonomi yang tinggi membuat seseorang memilih dalam membeli makanan yang bergizi dan bervariasi (Pipes LP dalam Setiawan, Machmud dan Masrul, 2018).

Keluarga dengan pendapatan yang rendah mampu mengelola makanan yang 
bergizi dengan bahan yang sederhana dan murah maka pertumbuhan bayi juga akan menjadi baik. Pendapatan yang diterima tidak sepenuhnya dibelanjakan untuk kebutuhan makan pokok melainkan untuk kebutuhan lainnya. Tingkat pendapatan yang tinggi belum tentu dapat menjamin status gizi baik bagi balita, karena tingkat pendapatan belum tentu teralokasikan dengan cukup untuk keperluan asupan gizi yang seimbang ${ }^{15}$.

Anak kerdil/pendek yang terjadi di Indonesia sebenarnya tidak hanya dialami oleh rumah tangga/keluarga yang miskin dan kurang mampu, karena stunting juga dialami oleh sejumlah rumah tangga/keluarga yang tidak miskin/yang berada di atas $40 \%$ tingkat kesejahteraan sosial dan ekonominya. Berdasarkan estimasi dari Riskesdas (tingkat stunting) dan proyeksi populasi BPS mengemukakan bahwa kondisi anak stunting juga dialami oleh keluarga/rumah tangga yang tidak miskin ${ }^{16}$.

\section{Hubungan Pengetahuan Ibu dengan Stunting Sangat Pendek dan Pendek}

Berdasarkan hasil penelitian didapatkan data bahwa Ibu dengan pengetahuan baik cenderung memiliki balita sangat pendek lebih besar dari Ibu dengan pengetahuan kurang. Tidak terdapat hubungan yang signifikan antara pengetahuan Ibu dengan stunting sangat pendek dan pendek pada balita stunting di Kecamatan Sawah Besar Kota Jakarta Pusat. Hasil penelitian ini sejalan dengan penelitian Ni'mah dan Muniroh (2015) yang menyatakan bahwa tidak ada hubungan antara tingkat pengetahuan ibu dengan wasting dan stunting pada balita keluarga miskin di Kecamatan Balen Kabupaten Bojonegoro.

Terjadinya stunting terkait dengan asupan zat gizi pada saat Ibu hamil dan asupan zat gizi pada saat bayi berumur 0-24 bulan. Asupan zat gizi anak sejak dalam kandungan sampe anak berumur 24 bulan akan berpengaruh kedalam status gizi anak kedepannya. Oleh karena itu, Ibu dengan tingkat pengetahuan yang baik kemungkinan besar akan dapat mengasuh anaknya dengan baik khusunsya pada pada pemberian asupan gizi. Penelitian ini menjelaskan bahwa Ibu dengan pengetahuan baik cenderung memiliki balita stunting. Hal ini dikarenakan, pengetahuan yang para Ibu dapatkan kurang diterapkan secara maksimal dalam mengasuh anaknya terlebih khusus dalam praktik pemberian asupan gizi anak dari sejak dalam kandungan sampai anak menginjak umur 24 bulan.

Menurut Notoatmodjo dalam Ni'mah dan Muniroh (2015), tingkat pengetahuan ibu yang tinggi tidak menjamin memiliki balita dengan status gizi yang normal. Ibu yang memiliki penegetahuan baik diharapkan mampu mengaplikasikan pengetahuan yang dimiliki dalam kehidupan sehari-hari. Namun, perilaku selain dipengaruhi oleh tingkat pengetahuan juga dapat dipengaruhi lingkungan, sosio ekonomi dan sosio budaya ${ }^{4}$.

\section{Hubungan ASI Eksklusif dengan Stunting Sangat Pendek dan Pendek}

Berdasarkan hasil penelitian didapatkan data bahwa balita yang tidak mendapatkan ASI eksklusif cenderung menderita sangat pendek lebih besar dari balita yang mendapatkan ASI eksklusif. Didapatkan hubungan yang signifikan antara ASI eksklusif dengan stunting sangat pendek dan pendek pada balita stunting di Kecamatan Sawah Besar Kota Jakarta Pusat. Hasil ini sejalan dengan penelitian Aridiyah dkk. (2015) dan Wahdah dkk. (2015) yang menyatakan bahwa kejadian stunting pada anak balita dipengaruhi oleh variabel pemberian ASI eksklusif dan penelitian ini menunjukkan bahwa kejadian stunting secara signifikan berhubungan dengan pemberian ASI eksklusif, serta memperlihatkan bahwa anak yang tidak mendapatkan ASI eksklusif lebih berisiko untuk menderita stunting dibandingkan anak yang diberikan ASI secara eksklusif.

Pemberian ASI eksklusif pada bayi usia 0-6 bulan dan MPASI usia 6-24 bulan sudah terbukti dapat mengoptimalkan kecerdasan dan tumbuh kembang anak, ASI dapat mencegah terjadinya penyakit pada anak seperti kelebihan gizi dan kekurangan gizi karena ASI merupakan makanan yang sesuai untuk bayi. Tetapi banyak masyarakat masih belum benar dan tepat dalam memberikan ASI eksklusif untuk bayi umur 0-6 bulan dan MPASI pada bayi umur 6-24 bulan ${ }^{17}$.

\section{Hubungan Ragam Makanan dengan Stunting Sangat Pendek dan Pendek}

Berdasarkan hasil penelitian didapatkan data bahwa balita yang mengonsumsi makanan beragam cenderung menderita sangat pendek lebih besar dari balita pendek yang tidak mengonsumsi makanan beragam. Tidak 
terdapat hubungan yang signifikan antara ragam makanan dengan stunting sangat pendek dan pendek pada balita stunting di Kecamatan Sawah Besar Kota Jakarta Pusat. Hasil penelitian ini sejalan dengan penelitian Widyaningsih dkk. (2018) mengemukakan bahwa ada hubungan antara keragaman makanan dengan perbedaan sangat pendek dan pendek pada balita.

Keragaman makanan merupakan gambaran dari kualitas makanan yang dikonsumsi balita. Semakin beragam makanan yang dikonsumsi oleh balita maka akan semakin baik kualitas pangan balita. Keragaman pangan balita akan memperlihatkan pemilihan makanan yang tepat bagi balita. Apabila kualitas makanan yang dikonsumsi balita baik maka akan mencukupi kebutuhan gizi balita dengan baik, selain itu balita juga tidak akan merasa bosan setiap kali akan makan. Kebutuhan gizi bila terpenuhi dengan baik akan menghindari anak dari malnutrisi. Dalam penelitian terlihat bahwa sedikit lebih banyak balita stunting yang mengonsumsi makanan beragam dibandingkan balita mengonsumsi makanan beragam. Hal ini dikarenakan sudah banyak Ibu yang mulai membiasakan anak untuk mengonsumsi makanan beragam. Meskipun makanan yang dikonsumsi balita stunting lebih banyak yang beragam tetapi makanan yang dikonsumsi adalah makanan yang belakangan ini dikonsumsi makanan yang dikonsumsi sejak anak dalam kandungan sampai anak berusia 2 tahun (24 bulan), sehinga hal ini tidak dapat dikatakan bisa memengaruhi keadaan status gizi anak saat ini. Ragam makanan yang dikonsumsi akan berpengaruh kepada status gizi di masa yang akan datang ${ }^{18}$.

\section{Hubungan Pola asuh dengan Stunting Sangat Pendek dan Pendek}

Berdasarkan hasil penelitian didapatkan data bahwa balita dengan pola asuh kurang cenderung menderita sangat pendek lebih besar dari balita dengan pola asuh baik. Terdapat hubungan yang signifikan antara pola asuh dengan stunting sangat pendek dan pendek pada balita stunting di Kecamatan Sawah Besar Kota Jakarta Pusat. Hal ini sejalan dengan hasil penelitian Utami (2016) dan Jayanti (2015) yang menunjukkan bahwa terdapat hubungan yang signifikan antara pola asuh gizi/nutrisi dengan kejadian stunting. Lain halnya dengan hasil penelitian aisyah dkk.
(2019), Hayyudini dkk. (2017) dan Ni'mah dan muniroh (2015) yang menyatakan bahwa tidak ada hubungan antara pola asuh gizi, pola asuh maupun pola asuh keluarga terhadap kejadian stunting.

Menurut UNICEF/Lancet masalah stunting terutama disebabkan karena adanya pengaruh dari pola asuh, cakupan dan kualitas pelayanan kesehatan, lingkungan dan ketahanan pangan. Pola asuh (caring) terdiri dari Inisiasi Menyusui Dini (IMD), menyusui eksklusif sampai dengan 6 bulan dan pemberian ASI lalu dilanjutkan dengan makanan pendamping ASI (MPASI) sampai dengan 2 tahun merupakan proses untuk membantu tumbuh kembang bayi dan anak ${ }^{3}$.

Menurut Menteri Kesehatan Nila A Moeloek dalam Rapat Koordinasi Kependudukan, Keluarga Berencana dan Pembangunan Keluarga (KKBPK) menjelaskan bahwa Praktik pengasuhan yang tidak baik merupakan salah satu faktor multi dimensi yang menyebabkan stunting dan intervensi paling menentukan pada 1000 HPK.. sama halnya, menurut Dewan Pembina Perhimpunan Dokter Gizi Medik Indonesia (PDGMII) Prof Fasli Jalal menyatakan bahwa keterlibatan masyarakat dan pengetahuan yang benar terhadap pola asuh anak memegang kunsi utama dalam pencegahan stunting ${ }^{8}$.

Dalam penelitian ini, pola asuh kurang baik menjadi salah satu masalah penting yang menyebabkan terjadinya stunting pada balita di Kecamatan Sawah Besar Kota Jakarta Pusat. Dikarenakan praktik pola pengasuhan yang tidak baik akan menyebabkan pemilihan dan pemberian asupan makanan kepada anak yang tidak optimal terlebih khusus dalam praktik pemberian makanan bagi anak saat sejak dalam kandungan hingga menginjak usia 2 tahun (24 bulan).

\section{Hubungan Riwayat Penyakit dengan Stunting Sangat Pendek dan Pendek}

Berdasarkan hasil penelitian didapatkan data bahwa balita sangat pendek yang memiliki riwayat penyakit lebih besar dibandingkan balita sangat pendek yang tidak memiliki riwayat penyakit. Tidak terdapat hubungan yang signifikan antara riwayat penyakit dengan stunting sangat pendek dan pendek pada balita stunting di Kecamatan Sawah Besar Kota Jakarta Pusat. Hal ini berbeda dengan hasil penelitian Aridiyah dkk., (2015) dan Setiawan (2018) yang 
menunjukkan bahwa terdapat hubungan antara riwayat penyakit infeksi dengan perbedaan sangat pendek dan pendek.

Penyakit infeksi disebabkan oleh higiene dan sanitasi yang buruk (misalnya diare dan kecacingan) dapat menganggu penyerapan nutrisi pada proses pencernaan. Beberapa penyakit infeksi yang diderita anak dapat menyebabkan berat badan turun. Apabila kondisi ini terjadi dalam waktu yang cukup lama dan tidak disertai dengan pemberian asupan yang cukup untuk proses penyembuhan maka dapat mengakibatkan stunting ${ }^{3}$.

Penyakit infeksi dapat menurunkan asupan makanan, mengganggu absorbsi zat gizi, menyebabkan hilangnya zat gizi secara langsung dan meningkatkan kebutuhan metabolik. Selain itu, terdapat interaksi bolakbalik antara status gizi dengan penyakit infeksi. Malnutrisi bisa meningkatkan risiko infeksi, sedangkan infeksi dapat menyebabkan terjadinya malnutrisi. Apabila kondisi ini terjadi dalam waktu yang cukup lama dan tidak segera diatasi maka dapat menurunkan asupan makanan dan mengganggu absorbsi zat gizi, sehingga meningkatkan risiko terjadinya stunting pada balita ${ }^{13}$.

Penyakit infeksi memang dapat memengaruhi status gizi seseorang khususnya anak balita. Pada umumnya, jika anak terinfeksi penyakit akan memiliki nafsu makan yang kurang juga dan secara langsung menyebabkan asupan makan berkurang sehingga gizi anak tidak akan bisa tercukupi. Akan tetapi, penyakit infeksi dapat memengaruhi stunting apabila durasi terinfeksinya cukup lama yang menyebabkan asupan makan akan terus berkurang dan menyebabkan anak kekurang zat gizi untuk tubuhnya.

\section{Hubungan Pola Istirahat dengan Stunting Sangat Pendek dan Pendek}

Berdasarkan hasil penelitian didapatkan data bahwa balita sangat pendek dengan pola istirahat kurang lebih besar dibandingkan balita sangat pendek yang dengan pola istirahat baik. Tidak terdapat hubungan yang signifikan antara pola istirahat dengan stunting stunting pada balita stunting di Kecamatan Sawah Besar Kota Jakarta Pusat. Penelitian ini sejalan dengan penelitian Simanjuntak, Herlina dan Bayhakki. (2015) yang menunjukkan bahwa tidak ada hubungan kualitas tidur terhadap wasting dan Simarmata dkk (2017) yang menyatakan bahwa tindak ada hubungan bermakna antara status gizi dengan gangguan tidur.

Menurut Simarmata dkk. (2017), setiap kategori status gizi persentase responden dengan gangguan tidur lebih tinggi dibandingkan dengan yang tidak memiliki gangguan tidur. Faktor-faktor yang dapat memengaruhi tidur pada anak adalah keadaan anak yang ketakutan, suara bising, kecemasan karena merasa terpisah dengan orangtua, dan jika anak dalam keadaan sakit dapat menjadi faktor yang mengganggu tidur anak ${ }^{19}$.

Menurut Hidayat dalam Simarta dkk. (2017), masa kanak-kanak adalah waktu pertumbuhan fisiologis dan neurokognitif secara cepat dimana setiap deskripsi pola tidur harus tercakup. Pola tidur anak mengikuti urutan perkembangan yang khas dengan peningkatan bertahap kedalaman tidurnya dan terjadinya siklus tidur yang teraur. Dalam hal ini mungkin jam tidur dan durasi tidur pada anak yang memengaruhi kualitas tidur yang baik ataupun buruk pada anak ${ }^{19}$.

Berdasarkan hasil pengamatan dan wawancara dengan responden, pola tidur anak di kecamatan Sawah Besar sebenarnya sudah cukup baik dan durasi tidurnya pun sudah lumayan cukup. Akan tetapi, untuk hal jam tidur setiap malamnya, intensitas tidur siang yang tidak selalu dilakukan dan kebiasaan seperti pemadaman lampu saat tidur belum dilakukan dengan baik.

\section{Hubungan Aktivitas Fisik dengan Stunting Sangat Pendek dan Pendek}

Berdasarkan hasil penelitian didapatkan data bahwa balita sangat pendek dengan aktivitas fisik ringan lebih besar dibandingkan balita sangat pendek yang dengan aktivitas fisik berat. Tidak terdapat hubungan yang signifikan antara pola istirahatdengan perbedaan sangat pendek dan pendek pada balita stunting di Kecamatan Sawah Besar Kota Jakarta Pusat. Berbeda halnya dengan penelitian Harahap (2015) yang menunjukkan aktivitas fisik memilki hubungan dengan kejadian stunting pada anak. Aktivitas fisik sedang memberikan efek protektif terhadap kejadian stunting dibandingkan dengan dengan aktivitas fisik tinggi. Keseimbangan antara energi yang dikonsumsi dan energi yang dikeluarkan adalah faktor risiko terjadinya stunting pada anak dengan aktivitas fisik rendah dan tinggi. Anak-anak dengan 
konsumsi makanan yang rendah diasumsikan tidak mempunyai aktivitas yang banyak karena mereka tidak mempunyai energi yang cukup untuk beraktivitas. Anak-anak dengan aktivitas fisik yang tinggi akan mengeluarkan banyak energi, jika konsumsi energi tidak mencukupi maka akan dilakukan pemecahan protein untuk memenuhi kebutuhan energi. Aktivitas fisik yang cukup dan sesuai diperlukan selama anak pada masa pertumbuhan ${ }^{20}$.

Usia balita adalah usia yang cukup aktif, usia dimana anak suka sekali bermain dengan teman maupun dengan mainannya. Akan tetapi, pada usia balita aktivitas yang dapat dikerjakan sebagian besar termasuk dalam kategori aktivitas ringan, mereka belum masuk sekolah dan belum bisa melakukan kegiatan-

\section{DAFTAR PUSTAKA}

1. Kementrian Kesehatan R. Ini Penyebab Stunting pada Anak. Biro Komun dan Pelayanan Masy [Internet]. 2018;1. Tersedia pada: http://www.depkes.go.id/article/view /18052800006/ini-penyebabstunting-pada-anak.html

2. Kementerian Kesehatan R. Buku Saku Pemantauan Status Gizi Tahun 2017 [Internet]. Hasil Pemantauan Status Gizi (PSG). 2017. Tersedia pada:

http://sehatnegeriku.kemkes.go.id/ba ca/rilis-

media/20170203/0319612/inilahhasil-pemantauan-status-gizi-psg2016/

3. Kementerian Kesehatan RI. Buletin Situasi Balita Pendek (Stunting) di Indonesia. Pus Data Inf Kementeri Kesehat Republik Indones. 2018;301(5):1163-78.

4. Ni 'mah C, Muniroh L. Hubungan Tingkat Pendidikan, Tingkat Pengetahuan dan Pola Asuh Ibu dengan Wasting dan Stunting pada Balita Keluarga Miskin. Media Gizi Indones. 2015; Vol. 10,:84-90.

5. Aisyah, Suyatno, Rahfiludin MZ. Faktor-faktor yang Berhubungan dengan Stunting pada Anak Kelas Satu di SDI Taqwiyatul Wathon, Daerah Pesisir Kota Semarang. J Kesehat Masy. 2019;7.

6. Rahman FD. Pengaruh Pola Pemberian Makanan Terhadap kegiatan berat lainnya. Aktivitas yang mungkin sekiranya tergolong cukup berat bagi balita adalah main diluar rumah bersama teman.

\section{KESIMPULAN}

Tidak ada hubungan antara usia Ibu, pendidikan Ibu, status pekerjaan Ibu, pendapatan keluarga, pengetahuan Ibu, ragam makanan, riwayat penyakit, pola istirahat dan akitivtas fisik dengan stunting sangat pendek dan pendek pada balita stunting usia 24 bulan59 bulan di Kecamatan Sawah Besar Kota Jakarta Pusat. Ada hubungan antara ASI eksklusif dan pola asuh dengan stunting sangat pendek dan pendek pada anak usia 24 bulan-59 bulan di Kecamatan Sawah Besar Kota Jakarta Pusat

Kejadian Stunting pada Balita (Studi di Wilayah Kerja Puskesmas Sumberjambe, Kasiyan dan Puskesmas Sumberbaru Kabupaten Jember. Indones Jorunal Heal Sci. 2018;10(1):15-24.

7. Dinas Kesehatan Provinsi DKI Jakarta. Profil Kesehatan DKI JAKARTA Tahun 2017 [Internet]. Profil Kesehatan DKI Jakarta tahun 2017. 2017. Tersedia pada: https://dinkes.jakarta.go.id/wpcontent/uploads/2018/09/PROFILKES-DKI-JAKARTA-TAHUN2017.pdf

8. BKKBN. Peran BKKBN di Balik Gerakan Penanggulangan Stunting. J Kel (Informasi Kependudukan, KB dan Pembang Keluarga). 2018;

9. Suku Dinas Kesehatan Jakarta Pusat. Rekapan Status Gizi Balita Berdasarkan EPPGBM Wilayah Kota Administrasi Jakarta Pusat. 2018.

10. Pratasis NN, Malonda NSH, Kapantow NH, Kesehatan F, Universitas $\mathrm{M}$, Ratulangi $\mathrm{S}$. Hubungan Antara Karakteristik Ibu dengan Status Gizi pada Balita di Desa Ongkaw Kecamatan Sinonsayang Kabupaten Minahasa Selatan. Fak Kesehat Masy Univ Sam Ratulangi. 2018;1-9.

11. Hayyudini D, Suyatno, Dharmawan Y. Hubungan Karakteristik Ibu, Pola Asuh dan Pemberian Imunisasi Dasar terhadap Status Gizi Anak Usia 12- 
24 Bulan (Studi di Wilayah Kerja Puskesmas Kedungmundu Kota Semarang Tahun 2017). J Kesehat Masy. 2017;5(4):369.

12. Wahdah S, Juffrie M, Huriyati E. Faktor Risiko Kejadian Stunting Pada Anak Umur 6-36 Bulan Di Wilayah Pedalaman Kecamatan SIlat Hulu, Kapuas Hulu, Kalimantan Barat. J Gizi dan Diet Indones. 2015;3(2):119-30.

13. Aridiyah FO, Ninna R, Ririanty M. Faktor-faktor yang Mempengaruhi Kejadian Stunting pada Anak Balita di Wilayah Pedesaan dan Perkotaan (The Factors Affecting Stunting on Toddlers in Rural and Urban Areas). e-Jurnal Pustaka Kesehat. 2015;3(1):163-70.

14. Setiawan E, Machmud R, Masrul. Faktor-faktor yang Berhubungan dengan Kejadian Stunting pada Anak Usia 24-59 Bulan di Wilayah Kerja Puskesmas Padang Timur Kota Padang Tahun 2018. J Fak Kedokt Univ Andalas. 2018;7(2).

15. Hapsari W. Hubungan Pendapatan Keluarga, Pengetahuan Ibu tentang Gizi, Tinggi Badan Orang Tua dan Tingkat Pendidikan Ayah dengan Kejadian Stunting pada Anak Umur 12-59 Bulan. 2018;(4). Tersedia pada:

http://publicacoes.cardiol.br/portal/ijc s/portugues/2018/v3103/pdf/3103009
.pdf\%0Ahttp://www.scielo.org.co/sci elo.php?script=sci_arttext $\&$ pid=S012 1 -

$75772018000200067 \& \operatorname{lng}=$ en\&tlng= en\&SID=5BQIj3a2MLaWUV4OizE \%0Ahttp://scielo.iec.pa.gov.br/scielo. php?script=sci

16. Tim Nasional Percepatan Penanggulangan Kemiskinan. 100 Kabupaten/Kota Prioritas untuk Intervensi Anak Kerdil (Stunting). 1 ed. Jakarta: Sekretariat Wakil Presiden Republik Indonesia; 2017. 302 hal.

17. Badan Penelitian dan Pengembangan Kesehatan. Riset Kesehatan Dasar (RISKESDAS) 2013. Lap Nas 2013. 2013;1-384.

18. Widyaningsih NN, Kusnandar K, Anantanyu S. Keragaman pangan, pola asuh makan dan kejadian stunting pada balita usia 24-59 bulan. J Gizi Indones. 2018;7(1):22.

19. Simarmata IYS, Mantik MFJ, Rampengan NH. Hubungan Status Gizi dan Gangguan Tidur pada Anak Sekolah Dasar di Kecamatan Tikala Manado. 2017;5-10.

20. Harahap H, Sandjaja, Soekatri M. Kepadatan Tulang, Aktivitas Fisik dan Konsumsi Makanan Berhubungan dengan Kejadian Stunting pada Anak Usia 6 - 12 tahun. J Gizi Indones. 2015;38(1):18. 